pp. $24-30$

\title{
PENGERTIAN INTERFACE MANAGEMENT DALAM ORGANISASI PROYEK KONSTRUKSI
}

\author{
Ipak Neneng Mardiah Bukit ${ }^{1}$ \\ ${ }^{1)}$ Program Studi Teknik Sipil, Fakultas Teknik, Universitas Samudra \\ Jl. Gampong Meurandeh, Kecamatan Langsa Lama Kota Langsa. \\ email : ipbukit@gmail.com
}

\begin{abstract}
Abstrak: Organisasi proyek konstruksi merupakan sebuah system yang kompleks karena terdiri dari banyak sekali pihak yang terlibat. Untuk itu perlu dilakukan sebuah manajemen koordinasi dan pengendalian dalam manajemen proyek agar hubungan antar pihak dalam proyek dapat berjalan dengan baik. Tujuannya adalah agar pelaksanaan pekerjaan berjalan mulus tanpa gesekan berarti antar individu. Interface management (IM) merupakan bagian yang penting dalam organisasi proyek. IM adalah system manajemen yang memastikan para pihak/stakeholders dapat bekerjasama, berkomunikasi dan tanggungjawab antar individu di dalam proses pelaksanaan konstruksi. Paper ini akan membahas definisi IM, permasalahan dan prosedur yang dilakukan agar organisasi proyek konstruksi dapat mendukung keberhasilan proyeknya. Diskusi ini menyimpulkan bahwa sebuah proyek akan berjalan lancar jika pimpinan proyek mengimplementasikan IM sejak awal pelaksanaannya.
\end{abstract}

Kata kunci : interface, konstruksi, manajemen, organisasi, proyek, stakeholder.

\begin{abstract}
Construction project organization is a very complex system that is involving many parties. To ensure the organization work properly, therefore a good management system is required. This is important to ensure all individual work in a pleasant working environment. The goal of the system is to avoid friction among people in the project site. Interface management (IM) becomes significant in the project organization. IM is a management system developed thus all the stakeholders in a project or every party in a process can work together, can communicate and be responsible to their works during the implementation process of construction. IM is project manager's job in management project. This paper will discuss IM definition, interfaces problems and IM procedures that should be implemented in order to achieve project success. The result of this discussion is a project will be efficiently generated if the project manager implements IM from the beginning of the project implementation.
\end{abstract}

Keywords : interfaces, construction, management, organization, project, stakeholders.

Keberhasilan pekerjaan konstruksi sangat tergantung kepada bagaimana para pihak yang terlibat di dalam proyek bersikap satu sama lain. Dalam sebuah proyek biasanya melibatkan banyak sekali organisasi/institusi/perusahaan/stakeholder yang berperan aktif maupun tidak. Besar kecilnya peran masing-masing stakeholder tetap menentukan jalannya proyek apakah sesuai dengan yang direncanakan.. Ada kalanya sebuah proyek melibatkan lebih dari satu institusi/instansi. Semakin banyak parties dalam proyek, semakin kompleks permasalahan yang dihadapi di dalammya. Contohnya pelaksanaan pekerjaan infrastruktur di sebuah daerah akan melibatkan beberapa instansi pemerintah daerah, misalnya pembangunan irigasi dan jalan inspeksi akan melibatkan Dinas Pekerjaan Umum dan Dinas Pertanian. Bagaimana menyatukan persepsi diantara kedua dinas ini tidak hanya bersifat teknis, 
akan tetapi juga bersifat manajerial. Padahal jika dijelaskan dalam suatu proyek akan juga terdiri dari pemilik, manajer proyek, perencana, penyelia, pelaksana dan subpelaksana. Semua pihak ini juga dituntut untuk dapat berkoordinasi dengan baik sesuai perannya masing-masing. Semua pihak yang terlibat di dalam proyek berpotensi untuk mencapai keberhasilan proyek, ataupun menjadikan proyek gagal.

Hubungan antara pihak di dalam organisasi proyek disebut interface management (IM). Walaupun IM sudah digunakan pada proyek-proyek besar terutama yang melibatkan teknologi tinggi seperti proyek luar angkasa dan system informasi namun proses IM yang lebih maju belum didukung oleh penelitian yang ekstensif (Chan, 2005;2). Di Indonesia, IM tidak terlalu dikenal, padahal system pengadaan barang dan jasa di Indonesia sangat kompleks dan melibatkan banyak stakeholders (Presiden RI, 2010;11). Paper ini akan membahas apa yang dimaksud dengan IM dan bagaimana mengimplementasikannya di dalam sebuah organisasi proyek konstruksi.. IM merupakan system manajemen yang tepat untuk menjelaskan hubungan antar pihak dalam proyek seperti komunikasi, koordinasi dan relasi antar stakeholders yang menentukan efektif tidaknya pelaksanaan proyek. Salah satu penyebab kegagalan proyek adalah karena begitu kompleksnya permasalahan koordinasi diantara stakeholders karena tidak adanya suasana kooperatif dalam proyek terutama untuk mega proyek (Shokri, S., Ahn, S., Lee, S., Haas, C.T., and Haas, R. C. G., 2016;04015069-1).

\section{DEFINISI INTERFACE MANAGEMENT}

Interface management

didefinisikan sebagai manajemen komunikasi, kerjasama dan tanggungjawab yang melintasi batasan umum diantara dua organisasi, tahapan, atau bentuk entitas pisik yang masing-masing berdiri sendiri (Chan, W.T., Chen, C., Messner, J. I., and Chua, D. K. H., 2005;646). Huang dkk (2008) merumuskan definisi IM berdasarkan beberapa penelitian sebelumnya sebagai berbagai permasalahan yang secara pisik dan fungsinya berkoordinasi atau dioperasikan diantara dua atau lebih pelaku/pihak (Huang, R. Y., Huang, C. T., Lin, H., dan Ku, W. H., 2008;53). Sementara itu Lin, Pe dan Wu dalam Huang et al (2008) percaya bahwa interfaces berlaku pada kejadian-kejadian, proses-proses, system-sistem, elemen-elemen dan penggunaan peralatan-peralatan jadi tidak hanya antar organisasi saja. Moris $(1979 ; 1)$ menyataan bahwa IM merupakan bidang kerja dari manajer proyek yaitu: planning, coordinating, dan controlling terhadap pekerjaan orang lain pada interfaces.

Berdasarkan definisi diatas maka dapat dijabarkan pengertian IM adalah sebagai berikut:

1. IM merupakan kerja seorang proyek manajer dalam pelaksanaan proyek melalui koordinasi, komunikasi, interdependency antar pihak-pihak

Volume 3, No. 1, Januari 2017 
yang bekerja di dalam suatu proses/kejadian di dalam sebuah organisasi proyek/antar subsistem proyek.

2. IM adalah manajemen penyelesaian masalah pisik dan fungsional di dalam dua atau lebih organisasi.

Dua pengertian tersebut terlihat memberikan perbedaan pada IM, namun sebenarnya memiliki arti yang sama yaitu hubungan kerjasama antar pihak didalamnya (organisasi ataupun proses) dan bagaimana orang yang bertanggungjawab terhadap jalannya kegiatan tersebut mampu mengkoordinasikan, mengkomunikasikan dan mengendalikan agar tujuan organisasi/proses dapat berjalan sesuai rencana. Penjelasan Moris menekankan tanggungjawab tersebut.

\section{Permasalahan dalam Interfaces}

Tujuan IM antara lain adalah menghindari gesekan diantara pelaku yang terlibat di dalam proyek, terutama mega proyek, dimana hal ini berhubungan langsung dengan keberhasilan manajer proyek mengantarkan hasil pekerjaan dengan kualitas yang sesuai permintaan konsumen/klien.

Banyaknya pihak yang terlibat di dalam pelaksanaan sebuah proyek menyebabkan munculnya permasalahan yang tidak disangka-sangka apabila proyek masih belum berjalan. Pihak-pihak yang terlibat seperti pemilik proyek, perencana, pelaksana, sub pelaksana, penyelia dapat saja menyebabkan permasalahan seperti disebutkan oleh Huang dkk berikut: tidak adanya kerjasama yang baik, terbatasnya rasa saling percaya, dan komunikasi yang tidak efektif dapat mengarah kepada permusuhan diantara pihak-pihak tersebut. Jika hal ini terjadi maka proyek berpotensi terjadi keterlambatan, pembengkakan biaya, penyelesaian masalah akan sulit dilakukan, terjadinya proses pengadilan dan kualitas proyek yang tidak tercapai (Moore et al seperti dikutip oleh Huang (2008;52).

Lebih jauh Huang et al (2008;54) menjelaskan permasalahan dalam IM adalah sebagai berikut: kontrak dan spesifikasi yang tidak mencukupi, masalah financial, masalah lingkungan dan hal lainnya. Tentu sangat mudah dipahami apabila kontrak tidak cukup menjelaskan begitu pula spesifikasi yang diharapkan tidak jelas, maka akan timbul masalah koordinasi di antara pihak yang terlibat. Akan muncul pemahaman yang berbeda terhadap isi kontrak, sehingga pekerjaan akan terkendala. Persamaan persepsi sangat penting di dalam IM, karena hal ini merupakan tujuan utama dalam manajemen proyek yaitu penyelesaian proyek sesuai scope yang disepakati dalam spesifikasi. Manajer proyek bertanggungjawab terhadap pencapaian hasil yang sesuai budget, waktu dan scope proyek (Morris,1979;6).

\section{PROJECT INTERFACES}

Tanggungjawab manajer proyek untuk memastikan proyek berjalan sesuai rencana waktu, biaya dan scope proyek juga berarti 
tanggungjawabnya untuk dapat mengkoordinasikan seluruh kelompok fungsional yang terlibat di dalam proyek. Oleh karena itu di dalam proyek yang terdiri dari beberapa kelompok yang bekerja sesuai fungsinya masing-masing. Misalnya departemen keuangan, bagian perencanaan, bagian pengawasan, bagian pemasaran dan lain-lain. Setiap kelompok memiliki tanggungjawab yang berbeda, namun harus dengan tujuan proyek yang sama yaitu mengantarkan hasil proyek yang tepat waktu, tepat biaya dan tepat sasaran (scope). Menurut Morris $(1979 ; 6)$ manajer pada kelompok fungsional proyek bertanggungjawab untuk:

1. Menyelesaikan pekerjaan dalam bidangnya sesuai waktu, biaya dan sasarannya.

2. Membuat kebijakan fungsional dan pegangan prosedur.

3. Menyediakan staf yang terlatih.

4. Mempertahankan keunggulan teknis.

Kewajiban manajer proyek (Morris, 1979;6) dalam interfaces adalah:

1. Merencanakan, mengkoordinasikan, dan mengendalikan kerja kelompok fungsioal untuk mencapai tujuan proyek.

2. Mendesak dan menjamin tindakan perbaikan untuk memastikan tercapainya target proyek.

Pavitt dan Gibb seperti dikutip oleh Daniels et al $(2014 ; 1)$ menjelaskan bahwa terdapat tiga tipe interfaces dalam proyek konstruksi; physical, contractual dan organizational interfaces. Physical interfaces adalah hubungan pisikal yang terjadi di antara elemen atau komponen bangunan. Contractual interfaces adalah hubungan antar kegiatan yang diatur dalam kontrak kerja proyek. Sedangkan organizational interfaces adalah hubungan kerja antar personal di dalam organisasi proyek konstruksi. Kesemua hubungan - dari ketiga tipe - yang disebutkan tadi merupakan hubungan saling ketergantungan (interdependent) diantara elemen yang terlibat di dalam proyek konstruksi.

\section{DISKUSI}

Proyek Konstruksi adalah sebuah system kerja yang sangat kompleks karena melibatkan banyak sekali komponen atau elemen di dalamnya. Setiap elemen/bagian dalam system tersebut memiliki peran yang penting. Salah mengambil keputusan terhadap kinerja setiap elemen akan membahayakan kualitas dan kinerja system. Oleh karenanya sebagai sebuah system, organisasi proyek konstruksi memerlukan suatu system manajement yang telah disepakati dalam kontrak.

System organisasi dalam proyek konstruksi sebaiknya terintegrasi dengan seluruh kelompok kerja di dalamnya (interdependency between subsystems). Untuk mengatur kinerja subsystems tersebut diperlukan sebuah strategi yang dapat menjelaskan fungsi masing-masing bagian 
tanpa bertubrukan dengan bagian yang lainnya (Morris, 1979;3). Berikut akan dijelaskan hubungan antar subsystem di dalam organisasi proyek yang terintegrasi.

\section{Struktur Proyek}

Sebuah proyek terdiri dari beberapa kelompok kerjayang saling berhubungan satu sama lain. Paling tidak ada 4 (empat) kelompok kerja di dalam sebuah proyek konstruksi (Morris, 1979;8) yaitu:

1. Kelompok independen perencana dan pengendali/pengawas.

2. Kelompok independen manajer proyek.

3. Kelompok fungsional.

4. Untuk multiproject biasanya terdapat kelompok sub-project.

Di Indonesia kelompok kerja tersebut sangat umum dengan struktur organisasi sederhana. Perencana dan pengawas bekerja dan bertanggungjawab kepada manajer proyek dan manajer proyek sebagai agen dari pemilik bertanggungjawab terhadap keberhasilan proyek. Akan tetapi kelompok fungsional tidak biasa dipisahankan dari dua kelompok pertama. Kelompok fungsional terdiri dari insinyur, logistic, pengadaan, quality assurance dan lain-lain. Kelompok fungsional ini penting keberadaannya, dan berfungsi sangat besar terhadap jalannya pelaksanaan proyek. Berikut digambarkan struktur organisasi pemilik proyek:

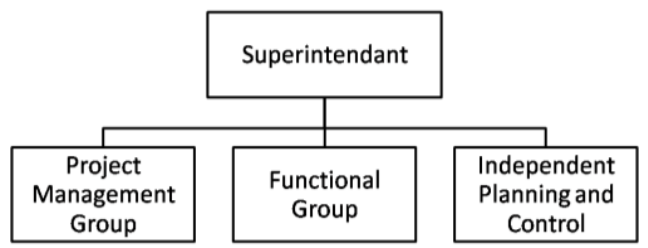

Gambar 1. Struktur organisasi pemilik proyek Sumber: Morris (1979)

Semua kelompok kerja di dalam organisasi proyek harus dapat dikoordinir dan dikontrol kinerjanya. Dipohusodo (1996;44) menyebutkan konsep ini sebagai konsep pendekatan Tim. Pendekatan yang dimaksud oleh Dipohusodo adalah kemampuan pejabatpejabat di dalam organisasi proyek untuk membentuk kerjasama yang baik guna mengkoordinir dan mengendalikan jalannya proyek. Tim proyek harus dapat menjaga keterpaduan antar elemen di dalam proyek dengan cara menciptakan ruang intensitas dan hubungan komunikasi antar individu di dalam proyek tersebut.

Konsep pendekatan tim ini sama dengan prinsip IM yang dijelaskan oleh Morris dalam Chan $(2005 ; 646)$ bahwasanya IM mengarah kepada:

1. Definisi konseptual dari banyak subsistem yang harus diurus dalam sebuah proyek.

2. Identifikasi interfaces pada prinsip subsistem yang membutuhkan perhatian manajemen.

3. Pemilihan metode yang tepat untuk menyelesaikan masalah dalam interfaces di dalam subsistem.

Dipohusodo (1996;44) menekankan bahwa konsep pendekatan tim tidak hanya ditujukan 
kepada individu di dalam proyek, akan tetapi semangat Tim Proyek dapat diperluas dengan mengikutsertakan para konsultan, kontraktor, pemasok material dan lain-lain. Jika diperluas lagi, semangat Tim Proyek/IM dapat pula mengikursertakan pejabat-pejabat dari stakeholder yang terlibat, misalnya Kepala Dinas-Kepala Dinas, BUMN, BUMD dan instansi yang bertanggungjawab dalam pengadaan barang dan jasa di pemerintahan.

Dengan kata lain interface management memiliki pengertian yang sangat luas, dalam hal ikatan/interdependency pihak dalam proyek.

\section{Prosedur IM}

Untuk mengenal IM lebih jauh Chan (2005;646) mengatakan langkah awal dalam pelaksanaan IM adalah dengan mengenal batasan dan hubungan saling ketergantungan (boundaries dan interdependencies) dalam subsistem yang terlibat pada proyek. Dua elemen tersebut merupakan elemen dasar dalam interfaces. Namun kedua elemen tersebut bisa terdiri dari banyak sekali item tergantung kondisi subsistem yang terlibat.

Chan $(2005 ; 647)$ menyarankan 4 langkah yang harus dilakukan dalam IM: (1) Identifikasi interfaces, (2) Penyederhanaan interfaces, (3) Prioritas interfaces, dan (4) Mencocokkan masing-masing interfaces.

Menurut Morris seperti dikutip oleh Chan $(2005 ; 647)$ interaksi antar subsistem dalam proyek dikenal dua tipe: (1) Static Interfaces/ongoing interfaces dan;

Dyanamic Interfaces/lifecycle interfaces.
Yang pertama adalah interaksi antar subsistem yang sedang bekerja dan tidak berubah sebagaimana proyek yang berubah. Sedangkan yang kedua adalah fungsi dari pola hubungan/interdependencies ikut berkembang sebagaimana proyek yang juga berubah secara kontinyu. Morris percaya bahwa dynamic interfaces adalah yang paling penting untuk dikenali karena berhubungan dengan jadwal kegiatan proyek yang kontinyu dan juga karena proses awal dari kegiatan proyek berperan besar secara manajerial.

\section{KESIMPULAN}

Dari diskusi yang tentang IM ini maka dapat disimpulkan bahwa IM merupakan bagian penting di dalam organisasi proyek konstruksi. Koordinasi dan pengendalian akan dapat dilakukan dengan baik jika para pihak yang terlibat di dalam sebuah proyek menyadari pentingnya semangat tim sehingga tujuan proyek dapat dicapai seperti yang diharapkan.

\section{DAFTAR PUSTAKA}

Chan, W.T., Chen, C., Messner, J. I., and Chua, D. K. H. (2005). Interface management for China's BuildOperate-transfer Projects. Journal of Construction Engineering Management. 131(6), 645-655.

Daniels, C., Farnsworth, C. B., Weidman, J. (2014). Interface Management on Megaprojects: A Case Study. $50^{\text {th }}$ ASC Annual International 
Conference

Associated

Proceedings.

Construction.

Dipohusodo, I. (1996). Manajemen

Proyek \& Konstruksi. Penerbit

Kanisius, Yogyakarta: Anggota IKAPI.

Huang, R. Y., Huang, C. T., Lin, H., dan

Ku, W. H. (2008). Factor Analysis

of Interface Problems Among

Construction Parties-A Case Study

of MRT. Journal of Marine Science and Technology. 16(1). 52-63.

Presiden RI. (2010). Peraturan Presiden Republik Indonesia No. 54 Tahun 2010 Tentang Pengadaan Barang dan Jasa. Jakarta.
Shokri, S., Ahn, S., Lee, S., Haas, C.T., and Haas, R. C. G. (2016). Interface Management Process for Managing Risks in Complex Capital Project. Journal Construction Management. 142(2).

Morris, P. W. G. (1979). Interface Management- an Organization theory Approach to Project Management. Project Management Quarterly, Booz, Allen \& Hamilton International, Paris. Diunduh pada 1 Januari 2017 dari https://www.pmi.org/learning/librar $\mathrm{y} /$ interface-management-theoryapproach-pm-5729. 